\title{
Rеввавсн автісі: Farm women decision making in integrated activities of Barmer district of Rajasthan
}

\author{
Sonali Sharma, Pradeep Pagaria, S. Das, B.R. Morwal, Hans Raj Sain and S.R. \\ Bana
}

Article Chronicle: Received :

26.04.2018;

Revised :

09.06.2018;

Accepted :

23.06.2018

\section{$\underline{\text { KEY WoRds : }}$}

Activities,

Agricultural, Decision

making,

Empowerment,

Women
SUMMARY : The women's contribution in the farming sector with respect to participation and decision making has largely been ignored. Though women performed more than four-fifth of agricultural work, their decision were accepted less than one-third of the case. The objective of present study were to find out women and their role in farming decision. The present study was conducted in Barmer district of Rajasthan. There are 3 block namely Barmer, Sheo, Chohtan. Forty women from each block were selected randomly thus making a total sample of 120 were interviewed with structure interviewed schedule. Results revealed that the male member of the family participated in decision making process of farm activities. This is not surprising because the joint family system is still prevalent where women have no role to play in decision making. In case of selection of seeds, quality of seeds, type of pesticide, time of harvesting, vaccination, calving of animals, foods of animals, maintenance of agricultural equipment, applying fertilizer, all decision were taken by elder person of the family. In all these cases women's decision was almost negligible. Further, more than 50 per cent of decision in the area of home science were taken by the women such as preservation of fruits and vegetables, food to be cooked, income of the family, saving in the family and child care practices. Further it showed that although women earned and saved the money by working in the field but their decisions were still centered to the kitchen only. It was also concluded that in financial matter, the involvement of women was less.

How to cite this article : Sharma, Sonali, Pagaria, Pradeep, Das, S., Morwal, B.R., Sain, Hans Raj and Bana, S.R. (2018). Farm women decision making in integrated activities of Barmer district of Rajasthan. Agric. Update, 13(3): 275-278; DOI : 10.15740/HAS/AU/13.3/275-278. Copyright@2018: Hind Agri-Horticultural Society.
Author for correspondence :

Sonali Sharma

Krishi Vigyan Kendra,

Barmer I (Rajasthan)

India

See end of the article for

authors' affiliations 